\title{
Intermediary languages at the stage of pre-university training
}

\author{
Alina Aleksandrovna Pozdnyakova ${ }^{{ }^{*}}$, Galina Vasilyevna Kuznetsova ${ }^{1}$, Tatiana Evgenievna \\ Kolyadina $^{1}$, Aleksandra Gennadievna Zaitseva ${ }^{1}$, and Larisa Yurievna Morozova ${ }^{2}$ \\ ${ }^{1}$ The Kosygin State University of Russia, Institute of International Education, Moscow, Russia \\ ${ }^{2}$ Moscow Pedagogical State University, Institute of International Education, Moscow, Russia
}

\begin{abstract}
The article considers the intermediary function of languages used at the stage of preparation of foreign applicants for admission to Russian universities. In a situation when the majority of foreigners' proficiency of the Russian language is not satisfactory, the process of studying special disciplines is significantly slowed down, and the lack of subject knowledge does not allow foreign students to successfully master their chosen specialty. In order to overcome these difficulties and solve the problem of providing students with initial subject knowledge, various forms of presentation of the material are used, but often they can be effective only if an intermediary language is used in the classroom - a common language that is more or less familiar to all the participants in the educational process. For this purpose, English is more often used in modern education. The choice of English as an intermediary language is explained by the role it plays in international communication and its wide representation in the educational process. Since there are different views in linguodidactics on the ways, methods, and "order" of introducing foreign language knowledge, special attention is paid to the expediency -inexpediency of using an intermediary language at different stages of teaching Russian in groups with heterogeneous ethnic composition. The conclusion is made about the importance of the designated problem and the need for its further development within the framework of ethnolinguistics and linguodidactics.
\end{abstract}

Keywords: Russian language, native language, intermediary (mediatic) function, specialty language

\section{$1 \quad$ Introduction}

At the stage of pre-university training, when the majority of foreign applicants do not possess sufficient knowledge of Russian, mastering the language of the specialty and special disciplines causes significant difficulties, which is why there is a need to use a common language. There is no consensus among linguodidactics specialists about the expediency of using an intermediary language in the conditions of the Russian language environment, but they often resort to its help. This is quite understandable. On the one

*Corresponding author: apozdnyakova@live.ru 
hand, in the absence of the teacher's knowledge of the students' native language, the need to use a "common" language is obvious. On the other hand, the development of the Russian language through someone else's, often "insufficiently felt", constant distinction from both the native language and the studied one (Russian), attempts to rely on another language base cause problems much more significant than it may seem at first glance. A brief description of these problems and ways to overcome them is the aim of this article. The tasks of the study are as follows: 1) identification of conditions dictating the use of the intermediary language in the learning process; 2) determination of the algorithm for introducing the intermediary language into the learning process; 3) formation of methodological recommendations on the use of the intermediary language in the educational process in the conditions of the Russian language environment.

\section{Methods}

To solve the tasks set in the work, the authors analyzed the linguistic, psychological, pedagogical, and sociological literature on the problem. The "basic" works of such scientists as Atkinson [1], Erikson [2], and Nisbett [3] have become important for understanding the essence of the mediatic function of language. Modern research on the mechanisms of switching language codes has helped to identify and describe the algorithm for introducing an intermediary language into the educational process; especially it is important to note the works of Yow, Patrycia, \& Flynn [4]; Ruiz-felter, Cooperson, Bedore, \& Peña [5]; MacSwan [6]; Kraemer, \& Fabiano-Smith [7]; Green [8]; Bogulski, Bice, \& Kroll [9]; Montanari, Ochoa, \& Subrahmanyam [10]; Rastelli [11].

In order to determine the conditions dictating the use of an intermediary language at the stage of preparation for higher education, the works of Gile [12, 13] (he studies the relationship between translation and interpretation in an academic environment) and Agrifoglio [14] (he conducted an experiment to identify the features of information perception in different types of translation and concluded that translation work performed in different conditions mobilizes certain cognitive resources and forms specific cognitive strategies) were used.

The data on the results of foreigners' education in a number of Moscow universities (Kosygin Russian State University, Moscow Pedagogical State University, etc.), statistical data on the experience of organizing foreign citizens' education in the specialty language $[15,16]$, open resources that train foreign citizens for the development of general education programs in Russian became the material for generalizations.

\section{$3 \quad$ Results}

According to the analysis of the results of the survey of foreign citizens (students of the Kosygin Russian State University and the Moscow Pedagogical State University), the authors identified the conditions dictating the use of an intermediary language in the process of introducing special disciplines. For the initial stage of training (pre-university), these conditions were as follows: 1) knowledge of the intermediary language by the members of the study group at a level not lower than A2, while the number of proficient in the language should be at least $80 \%$ of the group (while the experiment, the optimal results of assimilation of subject knowledge were shown by groups where the number of students who confirmed knowledge of English at levels A2, B1 and higher was in the range of $82-86 \%)$; 2) knowledge of the intermediary language by the teacher at a level not lower 
than B2 of general proficiency (in the experiment, 34\% of teachers confirmed their knowledge of English at this level; $12 \%$ of the teachers of the "successful groups" had certificates of additional professional training in a foreign language - for teaching it for special purposes); 3) the use of an intermediary language exclusively for solving educational tasks (for semanticizing lexical units, explaining grammatical constructions, checking the control of assimilation of new knowledge, analyzing and preventing errors), without activating it in everyday communication; 4) preservation in the Russian-speaking environment of the possibility of establishing "intermediary" parallels ("the Russian language is an intermediary") in the ratio of $60-40 \%$ for the introduction of new subject knowledge (for example, on educational excursions - to public institutions, factories, libraries, etc.).

For the advanced stage of education (I-III courses of Russian universities), the functions of the intermediary language should be limited and implemented in such situations as: 1) introduction of narrow subject knowledge (semantics of terms and professionalisms, differentiation of complex grammatical constructions of scientific speech, verification of understanding of scientific texts related to the interpretation of principles, laws, patterns, etc.); 2) use of the studied language in scientific and official events under the supervision of a teacher/curator (at scientific conferences, symposiums, industrial exhibitions, etc.); 3) writing scientific papers (abstracts, resume, articles) in Russian.

The algorithm of using the intermediary language in the educational process (if to talk about the language of the specialty) can be as follows: 1) "parallel vocabulary" - working with terminological units of a specific topic, their presentation in two languages; 2) "parallel text" - reading a special text (educational mini-text) in Russian and its translation into English or the native language of the student; 3) "parallel questions" - control of reading comprehension, carried out in two languages; 4) "summarizing"- oral generalization of the understood material in Russian, its fixation in a workbook with mandatory control of the correctness of the written Russian words and sentences. The last, fourth, stage is very important, because it helps to avoid fixing errors caused by interference between the Russian language and the intermediary language, which are numerous in a situation of parallel use of languages and therefore difficult to correct. These are graphic errors for mixing letters, lexical and grammatical errors, and errors for understanding and interpreting scientific realities.

The result of this study can also be considered the definition of a range of activities that allow: 1) to increase the level of subject knowledge of foreign students by mastering programs developed in the format of "two languages - one specialty"; 2) to provide access to relevant subject knowledge to a large number of foreign students through the proposed format of training programs; 3) to help teachers in organizing training using an intermediary language.

The authors should also add that the survey data obtained as part of the study of foreign citizens and teachers of foreign languages working with the specified contingent of trainees may be extremely useful for the formation of methodological recommendations for the creation of educational programs, textbooks, didactic materials that are not enough in the modern market of educational services (see [17]) and which can be widely used in the system of Russian additional education.

\section{Discussion}

Turning to the issues of obtaining initial subject knowledge by foreign students, the authors have identified three groups of the most pressing problems. 
The first group of problems is related to the different level of training of foreign applicants in the disciplines being mastered. More often it concerns additional humanitarian programs - subjects such as "History of Russia", "Russian Literature". For the most part, foreigners have a little idea of the facts of Russian history and are not at all guided by the logic of the historical and literary process. In this situation, a foreign language, acting as an intermediary one, assumes the role of a conductor of Russian culture and "Russian knowledge". This requires additional professional training of the teacher working with the group, the formation of certain competencies in the field of subject knowledge.

The second group of problems is differences in the types of teaching "preferred or adapted in the native country of a foreign student" [18]. The authors previously pointed out this fact in their works and drew attention to the fact that for each ethnic group, for each ethnic type, a specific type of teaching is predominant, due to the historical development, cultural and religious characteristics, the mentality of these people [18]. There have been numerous attempts in science to study ethnic stereotypes through the analysis of national methods and the identification of ways of teaching and raising children [2,3], but the problem of "unconscious elements of mentality" still remains as an open one. The mediatic function of the language (English or any other) in this case is to ensure interaction between all subjects of the educational process in order to avoid a "conflict" of the contacting teaching systems.

The third group of problems is related to the very possibility of using a particular language as an intermediary language. Being in the same group of listeners with different levels of proficiency in the proposed mediator language (students with no knowledge, foreign speakers, bilinguals) weakens its mediation role. With regard to bilinguals, for example, the assimilation of knowledge is difficult when learning is not carried out through the dominant language [9].

At the initial stage of teaching Russian and the language of the specialty, when foreign students (applicants) get acquainted with the grammatical structure and vocabulary of the language, basic constructions of the scientific style of speech, the volume of memorized material increases significantly. Therefore, the load on memory increases. In this case, the intermediary language helps to find adequate lexical and grammatical parallels in the learner's native language and facilitate the assimilation of information. The mediatic function of the language at this stage is realized in its application to identify interlanguage correspondences, as well as the formation of a "common contact zone" that allows interaction between all members of the study group.

The intermediary language at the initial stage of learning seems quite appropriate to the authors, since the work on transcoding information, according to many researchers, activates brain activity $[12,13]$ : this allows a foreigner to learn a foreign language more effectively and detect and correct errors that have resulted from interlanguage interference faster. However, it should be noted that with poor knowledge of a foreign language (both by the teacher and the student), there is a danger of "incorrect use" of it as an intermediary.

Preventing mistakes of foreign students (applicants) is an extremely important and difficult task. In this case, the teacher's qualifications should be sufficient to differentiate errors and separate those caused by interference from errors of other types (factual, logical, and also related to the lack of subject knowledge in their native language). This differentiation will allow choosing the most optimal methods and techniques for eliminating interference errors. One of the techniques can be, for example, the selection of educational material and the formation of exercises in the language of the specialty, taking into account the type of interference (lexical, morphological, syntactic). 


\section{Conclusion}

All of the above allows the authors to conclude about the importance of the designated problem and the expediency of its further development in two aspects: 1) in the aspect of ethnolinguistics, which presupposes a competent selection of interlanguage material from different fields of knowledge, 2) in the aspect of linguodidactics, which presupposes the development of new forms and methods of working with this material.

\section{References}

1. D. Atkinson, ELTJ, 4, 241-247 (1987)

2. E.H. Erikson, Childhood and Society. (Norton, New York, 1993)

3. R.E. Nisbett, The Geography of thought: how Asians and Westerners think differently.... and why. (Free press, New York, 2003)

4. W.Q. Yow, F. Patrycia, S. Flynn, Code-switching in childhood, in E. Nicoladis, S. Montanari (eds), Lifespan perspectives on bilingualism, 81-100. (American Psychological Association, Washington, 2016)

5. R. Ruiz-Felter, S.J. Cooperson, L.M. Bedore, E.D. Peña, Int J Lang Comm Disorders, 51(4), 368-383 (2016). https://doi.org/10.1111/1460-6984.12214

6. MacSwan, J. Codeswitching in adulthood, in E. Nicoladis, S. Montanari, (eds), Lifespan perspectives on bilingualism, 183-200. (American Psychological Association, Washington, 2016)

7. R. Kraemer, L. Fabiano-Smith, J Latin Edu, 16(4), 349-358 (2017). https://doi.org/10.1080/15348431.2016.1257429

8. D.W. Green, Languages, 3(2), 8 (2018). https://doi.org/10.3390/languages3020008

9. C.A. Bogulski, K. Bice, J.F. Kroll, Biling: Lang Cogn, 22(5), 1052-1067 (2018). https://doi.org/10.1017/S1366728918000858

10. S. Montanari, W. Ochoa, K. Subrahmanyam, J Child Lang, 46(5), 913-937 (2019). https://doi.org/10.1017/S0305000919000278

11. S. Rastelli, Lang Acquis, 26(4), 1-29 (2019). https://doi.org/10.1080/10489223.2019.1571594

12. D. Gile, Transl Res Interp Res: Trad, Gaps Synergies, 2(1), 10-34 (2004)

13. D. Gile, Basic Concepts and Models for Interpreter and Translator Training. (John Benjamins Publishing Company, Amsterdam/Philadelphia, 2015)

14. M. Agrifoglio, Interpreting, 6, $43-67$ (2004). https://doi.org/10.1075/intp.6.1.05agr

15. A.L. Arefyev, Obuchenie inostrannykh grazhdan v vysshikh uchebnykh zavedeniyakh Rossiiskoi Federatsii [Education of foreign citizens in higher educational institutions of the Russian Federation], in Statistical collection, 13. (Center for Sociological Research, Moscow, 2016)

16. Arefyev, A.L. Obuchenie inostrannykh grazhdan v obrazovatelnykh uchrezhdeniyakh vysshego obrazovaniya Rossiiskoi Federatsii [Training of foreign citizens in educational institutions of higher education of the Russian Federation], in Statistical collection, 17. (Pushkin State Institute of the Russian Language, Moscow, 2020) 
17. A.L. Arefyev, Sotsiologiya yazyka. Russkii yazyk. Sovremennoe sostoyanie i tendentsii rasprostraneniya $\mathrm{v}$ mire [Sociology of language. Russian language. The current state and trends of distribution in the world]. (Yurait, Moscow, 2020)

18. A.A. Pozdnyakova, Russian Russian spelling theory in the aspect of the formation of written speech of foreign students, in E.Ya. Titarenko (ed), Russian language in the multicultural world: collection of scientific articles of the III International Symposium, 2, 141-147. (ARIAL, Simferopol, 2019) 